\title{
Crohn Colitis
}

National Cancer Institute

\section{Source}

National Cancer Institute. Crohn Colitis. NCI Thesaurus. Code C35211.

Crohn's disease affecting the colon. 